\section{Earthquakes during May I940}

DuRING May 1940, eighteen earthquakes were registered at the Swiss Seismological Observatories of Basle, Chur, Neuchâtel and Zurich. The observers at Zurich have estimated the epicentres of the larger shocks as follows : May 1, in the province of Parma in Italy; May 4, in the Pacific Ocean east of the Kamchatka Peninsula near lat. $50^{\circ} \mathrm{N}$., long. $170^{\circ} \mathrm{E}$. ; May 7 , in Anatolia near lat. $42^{\circ} \mathrm{N}$., long. $34^{\circ} \mathrm{E}$.; May 19, one again near the Kamchatka Peninsula about lat. $49^{\circ} \mathrm{N}$., long. $158^{\circ} \mathrm{E}$., and one possibly in the Indian Ocean; May 24, one near Lima in Peru, also one in Central Germany.

The United States Coast and Geodetic Survey, in co operation with Science Service and the Jesuit Seismological Association, has made a preliminary determination of the epicentres of the earthquakes of May 11 and 17. On twelve seismometric reports the epicentre of the shock of May 11 was calculated to be near lat. $53 \cdot 2^{\circ} \mathrm{N}$., long. $172 \cdot 0^{\circ} \mathrm{E}$., which is near the island of Attu at the extreme western end of the Aleutian Islands. On the basis of instrumental reports from Fordham, Ottawa, Weston, Pittsburg, St. Louis, San Juan, and Huancayo, the epicentre of the earthquake of May 17 turned out to be near lat. $7 \cdot 9^{\circ} \mathrm{N}$., long. $81 \cdot 8^{\circ} \mathrm{W}$., which is just in the Pacific Ocean off the coast of Panama to the southwest of Pueblo Nuevo. Most of these shocks were also recorded at Kew.

\section{The Night Sky in July}

ON July 1 , the duration of night (sunset to sunrise) in the latitude of London is 7.5 hours ; astronomical twilight (the sun not greater than $18^{\circ}$ below the horizon) lasts all night until July 21. The moon is new on July 5 and full on July 19. The moon is in conjunction with Mars on July 6, with Jupiter and Saturn on July 28 and with Venus on July 31 . From the western parts of North America, Venus will be seen to be occulted by the moon at this conjunction in daylight. There is no bright planet conspicuous now in the evening skies, since Mars-the remaining member of the notable group of bright planets seen in the evenings of the early part of this year-is getting too close to the sun for observation. At the beginning of the month, Jupiter and Saturn rise within a quarter of an hour of each other not long after midnight (U.T.). Venus is the bright morning star seen about one hour before sunrise in the middle of July and $2 \frac{1}{2}$ hours before sunrise at the end of the month. The planet is increasing in brightness towards its maximum on August 2. Close groupings of Jupiter's four inner satellites (to be seen with binoculars) occur about $2 \mathrm{~h}$. on July 2, 12, 20, and 21. The ring system of Saturn is well open, the minor axis of the outer ellipse of the outer ring being greater than 13". The delta Aquarid meteors reach a maximum frequency about July 28.

\section{Announcements}

AT its meeting on June 21, the Council of the Lister Institute appointed Prof. C. R. Harington one of its representatives on the Governing Body of the Institute in succession to the late Sir Arthur Harden.

The Royal Meteorological Society has awarded its Howard Prize (an aneroid barometer, given annually for the best essay on a selected meteorological subject) to Cadet S. R. Pryor of the S.A.T.S. General Botha. The subject of the essay was "The Relation of Wind to Ocean Currents".

AT the annual general meeting of the Royal Geographical Society, it was announced that the King, having approved the awards of the Founder's and Patron's Medal, had signified through the Keepers of the Privy Purse that the gold medals could not be struck until after the War. The complete list of the Society's awards was given in NATURE of April 27, p. 665.

The annual general meeting of the British Social Hygiene Council will be held at British Medical Association House, Tavistock Square, W.C.I, at 4.30 p.m. on July 8 . The president, Sir Walter Langdon-Brown, will deliver an address on the activities of the British Social Hygiene Council since the outbreak of war. Tickets of admission may be obtained on application to the Secretary, B.S.H.C., Tavistock House South, Tavistock Square, W.C.1.

Dr. E. H. Cluver, secretary for public health and chief health officer for the Union of South Africa, has been appointed director of the South African Institute for Medical Research in succession to the late Sir Spencer Lister.

THE Plunket Society or Royal Society of New Zealand for the Health of Women and Children is proposing to erect a monument to its founder, Sir Truby King, whose system of infant feeding largely contributed to making the infantile mortality in New Zealand the lowest in the world.

A GIFT of a thousand dollars has been made to the International Association for the Prophylaxis of Blindness to promote research in ophthalmology. The subject chosen for a prize, which will be awarded on the occasion of the tenth International Congress of Ophthalmology, is simple non-inflammatory glaucoma. The address of the Association is 66 Boulevard Saint-Germain, Paris.

A PROGRAMME of some thirty papers on the applications of spectroscopy to problems of biology, chemistry, geology, metallurgy, medicine, physics, and various industries, has been arranged for the eighth summer conference on spectroscopy and its applications, to be held in the George Eastman Laboratories of the Massachusetts Institute of Technology during July 15-17. Further information can be obtained from Prof. George R. Harrison, Department of Physics, Massachusetts Institute of Technology, Cambridge, Massachusetts. 